Available Online at http://journal.umgo.ac.id/index.php/madu

\title{
TELAAH ARTIKEL ILMIAH EFEKTIFITAS KOMPRE DINGIN TERHADAP PENURUNAN INTENSITAS NYERI LUKA PERINEUM IBU POST PARTUM
}

\author{
${ }^{1}$ Ayu Agustina, ${ }^{2}$ Agustina Ningsi, ${ }^{3}$ Marhaeni, ${ }^{4}$ Sitti Mukarramah \\ ${ }^{1}$ Mahasiswa Jursan Kebidanan Poltekkes Kemenkes Makassar \\ Makassar, Indonesia, 90222 \\ E-mail:1_ayuagustinadwn@gmail.com²agustina_ningsih@poltekkes-mks.ac.id \\ 33arhaeni@poltekkes-mks.ac.id ${ }^{4}$ sitti_mukarramah@poltekkes-mks.ac.id
}

\begin{abstract}
Every mother who has undergone a labor process with a perineal wound will feel pain, pain that is felt by every post partum mother causes discomfort so that pain management is needed. The purpose of this journal study was to determine the effectiveness of cold compresses in reducing the intensity of perineal wound pain in post partum mothers. The literature search method was the Google Scholar database using the keywords cold compress, perineal wound pain. The study population in the article studied were post partum mothers who experienced perineal wound pain with the research sample in article one of 30 people, 15 people in article two, and 200 people in article three. Articles one and two used the one group pretest post test research design, while the pepper article three used the control group pretest post test. The article review process includes a review of the components of the article regarding the systematics of writing, language style, advantages and disadvantages. The results of the review of the article show that cold compresses are effective in reducing the intensity of post partum maternal perineal wound pain. This journal review is expected to be a reference in the implementation of perineal wound pain management in post partum mothers.
\end{abstract}

Keywords: Cold compress, Perineal Wound Pain Intensity. 


\section{PENDAHULUAN}

Salah satu permasalahan yang kerap dialami oleh ibu pasca bersalin secara normal adalah rasa nyeri di daerah perineum (Putri, 2016). Nyeri perineum dirasakan ibu akibat ruptur perineum pada kala pengeluaran. Hampir semua ibu dengan persalinan normal mengalami robekan perineum, baik dengan secara sengaja (episiotomi) maupun karena robekan yang spontan saat bersalin. Dari robekan tersebut ada yang perlu dijahit dan ada yang tidak perlu. Dari jahitan tersebut dapat pula menimbulkan nyeri (Rahmawati, 2015) .

Data WHO menunjukkan pada ibu bersalin terjadi 2,7 juta kasus rupture perineum dan akan terus meningkat hingga 6,3 juta di tahun 2050. Di Asia angka kejadian ruptur perineum mencapai $50 \%$ kasus sedangkan di Indonesia $85 \%$ ibu bersalin secara normal mengalami rupture perienum. Data yang diperoleh dari Puskesmas Mamajang per Januari hingga November 2019, dari 382 ibu bersalin $58 \%$ diantaranya mengalami ruptur perineum. Selain itu, Kejadian rupture perineum menyumbang AKI sebanyak 4-5\%, (Sigalingging and Sikumbang, 2018) sehingga diperlukan perawatan untuk mencegah peningkatan AKI.

Ibu melahirkan yang mengalami luka akibat rupture perineum perlu mendapatkan perhatian karena dapat menyebabkan disfungsi organ reproduksi wanita, sebagai sumber pendarahan dan infeksi yang dapat berakhir pada kematian atau sepsis (Wiyani and Adawiah, 2018). Selain itu nyeri yang dirasakan Ibu akan memberikan dampak berupa rasa tidak nyaman, sakit, dan takut untuk bergerak. (Rahmawati, 2011).

Penatalaksanaan nyeri dapat dilakukan dengan dua cara, yakni secara farmakologis dan non-farmakologis. Metode farmakologi yang sering kali digunakan untuk mengurangi nyeri adalah analgesik atau dengan menggunakan obat-obatan. Metode non-farmakologis yang dapat digunakan adalah dengan menggunakan metode sederhana berupa kompres dingin. Metode ini dapat meredakan nyeri dengan memperlambat kecepatan konduksi saraf dan menghambat impuls saraf, meyebabkan mati rasa, dan meningkatkan ambang nyeri dan dapat menimbulkan anestesi lokal. Kompres dingin bekerja dengan memperlambat kecepatan penghantaran saraf, sehingga impuls nyeri yang mencapai otak menjadi lebih sedikit (Rahmawati, 2015).

Penelitian yang dilakukan oleh Susilawati dan Hilda (2019) tentang 'Efektifitas Kompres Hangat dan Kompres Dingin Terhadap Intensitas Nyeri Luka Perineum Pada Ibu Post Partum di BPM Siti Julaeha Pekanbaru' menunjukkan rata-rata intesitas nyeri sebelum dilakukan intervensi adalah 4,80 dan setelah diberikan kompres hangat menjadi 2,60 sedangkan setelah diberikan kompres dingin rata-rata intesitas nyeri menjadi 1,33 .

Berdasarkan latar belakang tersebut menjadi dasar bagi penulis untuk melakukan telaah artikel ilmiha yang berkaitan dengan kompres dingin terhadap penurunan intensitas nyeri luka perineum ibu post partum.

\section{METODE PENELITIAN}

Pencarian literatur menggunakan database google scholar http://scholar.google.co.id dengan kata kunci intensitas nyeri luka perineum dan kompres dingin. Jumlah literatur yang didapatkan adalah 1500 dan diseleksi oleh penulis berdasarkan variabel yang akan ditelaah dan tahun publikasi artikel atau penelitian terbaru sesuai topik pada proposal penelitian yang telah diseminarkan dihadapan penguji.

\section{HASIL PENELITIAN}

\section{a. Kelebihan dan Kekurangan}

Berdasarkan hasil telaah ketiga artikel dapat dituliskan kelebihan atau kekurangan dari ketiga artikel baik yang dituliskan oleh penulis maupun berdasarkan hasil telaah.

Artikel satu menggunakan desain penelitian pre-eksperimental pada metode penelitiannya menggunakan desain penelitian one group pretest post test, yang menurut Sugiyono (2012) hasil yang diperoleh dapat 
Available Online at http://journal.umgo.ac.id/index.php/madu

lebih akurat karena peneliti dapat membandingkan hasil sebelum dan sesudah diberi perlakuan, sehinggan dapat dilakukan perbandingan antara tingkat nyeri sebelum dan sesudah tindakan untuk menentukan efektifitas pengaruh dari intervensi yang diberikan. Kekurangannya yaitu validasi internal dirasakan kurang karena tidak ada jaminan yang menyatakan hasil sebelum dan sesudah disebabkan oleh perlakuan.

Artikel tiga menggunakan desain penelitian pretest dan post test control group, keuntungannya menurut Sugiyono ( 2012) antara kelompok eksperimen dan kelompok control memiliki karakteristik yang sama karena diambil secara random dari populasi yang homogen. Kekurangannya adalah pengendalian berlebih terhadap kondisi penelitian sehingga tidak sesuai dengan situasi populasi dan adanya kesengajaan kelompok control tidak mendapatkan perlakuan.

Ketiga uraian mengenai desain penelitian dari ketiga artikel memiliki keuntungan dan kekurangannya masing-masing dalam menentukan pengaruh dan efektifitas dari kompres dingin terhdapa penurunan nyeri. Adapun hal yang ditemukan oleh penelaah pada bagian referensi artikel satu dan dua masih terdapat beberapa referensi yang belum memenuhi kaidah penulisan.

\section{b. Persamaan dan Perbedaan}

\section{1) Persamaan}

Persamaan pada ketiga artikel yang ditelaah adalah pada artikel satu dan dua menggunakan desain penelitian yang sama yaitu one group pretest post test. Persamaan lain dari ketiga artikel menolak hipotesis nol, yaitu hasil penelitian menunjukkan adanya pengaruh atau kompres dingin efektif dalam menurunkan intensitas nyeri luka perineum. Hasil penelitian disajikan dalam bentuk tabel dan narasi untuk memudahkan pembaca membaca hasil penelitian.

Berdasarkan sistematika penulisan dari ketiga artikel, penulisan referensi menggunakan gaya Harvard pada artikel satu dan dua sedangkan pada artikel tiga menggunakan gaya Vancouver.

\section{2) Perbedaan}

Berdasarkan hasil analisa melalui telaah tiga artikel dapat diketahui ketiga artikel masing-masing berbeda dalam Teknik pengambilan sampel. Artikel satu menggunakan Teknik purposive sampling, artikel dua menggunakan Teknik accidental sampling, sedangkan artikel tiga menggunakan random sampling.

Instrumen yang digunakan juga berbeda, artikel satu menggunakan Numerical Rating Scale (NRS), artikel dua tidak menuliskan instrument yang digunakan, sedangkan instrument pada artikel tiga Visual Analog Scale (VAS). Dari telaah yan dilakukan dapat diketahui beberapa persamaan pada ketiga artikel. Untuk desain penelitian, artikel satu dan dua menggunakan desain penelitian one group prestest post test, dan artikel tiga menggunakan desain penelitian

Selain itu, uji statistik yang digunakan berbeda. Artikel satu menggunakan uji MannWhitney, artikel dua menggunakan uji $\mathrm{T}$ berpasangan, sedangkan artikel tiga menggunakan uji Wilcoxon.

\section{c. Hasil Penelitian}

Berdasarkan hasil telaah ketiga artikel tidak ditemukan kesenjangan. Artikel satu menyebutkan bahwa terdapat perbedaan pada kompres hangat dan kompres dingin dimana kompres dingin lebih efektif dalam mengatasi nyeri luka perineum pada ibu post partum. Artikel dua menyimpulkan ada pengaruh terhadap pemberian kompres air dingin terhadap intensitas nyeri luka perineum ibu post partum dan hasil penelitian pada artikel tiga menunjukkan aplikasi bantalan gel dingin pada perineum dapat meredakan nyeri perineum dan meningkatkan kenyamanan post partum. Berdasarkan hasil penelitian Sulistiyani (2015) kompres dingin dapat membuat kulit menurunkan respon nyeri karena adanya pelepasan endorphin sehingga dapat memblokir transmisi serabut saraf sensori A-Beta yang lebih besar dan lebih cepat, juga dapat menurunkan transmisi nyeri pada serabut $\mathrm{C}$ dan delta A sehingga gerbang sinaps menutup transmisi impuls nyeri (Agustiningrum, 2019).

\section{KESIMPULAN}

Berdasarkan telaah artikel ilmiah yang telah dilakukan dapat ditarik kesimpulan bahwa 
kompres dingin dan bantalan gel dingin efektif dalam menguranfi nyeri luka perineum pada ibu post partum dan mengurangi ketidaknyamanan masa post partum. Artikels atu menunjukkan terdapat perbedaan antara kompres hangat dan kompres dingin dengan perbedaan penurunan intensitas nyeri dengan nilai rata-rata kompres dingin 1,33 lebih kecil dari kompres hangat 2,80 sehingga lebih efektif dalam menurunkan nyeri. Artikel dua menyebutkan terdapat pengaruh Intensitas nyeri setelah pemberian kompres air dingin pada ibu post partum dengan nyeri luka perineum di Rumah Sakit Bhayangkara Ambon. Artikel tiga menunjukkan tingkatan nyeri mengalami penurunan dan kenyamanan ibu mengalami peningkatan. Hal ini menunjukkan bahwa kompres dingin efektif dalam menurunkan tingkat nyeri luka perineum pada ibu post partum.

\section{REFERENSI}

Agustiningrum, R. D. (2019) Efektifitas Penggunaan Kompres Hangat dan Kompres Dingin Terhadap Tingkat Nyeri Pada Balita Pasca Imunisasi Ori Difteri. Program Studi Keperawatan Fakultas Keperawatan Universitas Airlangga.

Danim, S. and Darwis (2003) Metode Penelitian Kebidanan: Prosedur, Kebijakan, dan Etik. Cetakan I. Edited by M. Ester. jakarta: EGC.

Diana, A. and Pradana, A. (2017) Panduan Penulisan Naskah Ilmiah. jakarta: Lembaga Penerbit BALITBANGKES.

LIPI (2019) Penulisan Ilmiah.

Noor, H. M. (2019) Metode Penelitian. Ketiga. Makassar: Unit Penelitian Poltekkes Makassar.

Putri, A. D. (2016) 'Pengaruh Kompres Dingin Terhadap Tingkat Nyeri Luka Perineum Pada Ibu Nifas Di RSU PKU Muhammadiyah Bantul'.

Rahmawati, E. S. (2011) 'Pengaruh Kompres Dingin Terhadap Pengurangan Nyeri Luka Perineum Pada Ibu Nifas di BPS Siti Alfirdaus Kingking Kabupaten
Tuban ( The Influence of Cold Compress Towards Perineum Injury of Post-Partum', pp. 43-46.

Rahmawati, S. (2015) 'Perbedaan Efektivitas Kompres Dingin Dan Slow Stroke Back Massage Terhadap Penurunan Nyeri Perineum Pada Ibu Nifas Di Rumah Sakit Umum Daerah Pemekasan', p. 2015.

Sigalingging, M. and Sikumbang, S. R. (2018) 'Faktor Yang Berhubungan Dengan Terjadinya Rupture Perineum Pada Ibu Bersalin Di Rsu Imelda Pekerja Indonesia Medan 1', 1(3).

Sugiyono, 2012 (2012) Metode Penelitian Kuantitatif, kualitatif dan $R \& D$. Bandung: Alfabeta.

Susilawati, E. and Ilda, W. R. (2019) 'Efektifitas Kompres Hangat dan Kompres Dingin Terhadap Intensitas Nyeri Luka Perineum pada Ibu Post Partum di BPM Siti Julaeha Pekanbaru', JOMIS, 3(1), pp. 7-14.

Wiyani, R. and Adawiah, J. (2018) 'The Effectiveness Of Cold Compress To Wound Healing Of', Darul Azhar, 5(1), pp. 64-71. 